\title{
Hepatic LC3 II/I Ratio Is Not Modulated in Exercised Mice
}

\author{
Bruno Brieda MARAFON ${ }^{1}$, Ana Paula PINTO ${ }^{2}$, Alisson Luiz da ROCHA ${ }^{2}$, Rafael Lemes \\ ROVINA ${ }^{1}$, José Rodrigo PAULI ${ }^{3}$, Leandro Pereira DE MOURA ${ }^{3}$, Dennys Esper CINTRA ${ }^{3}$, \\ Eduardo Rochete ROPELLE ${ }^{3}$, Adelino Sanchez Ramos DA SILVA ${ }^{1,2}$
}

\author{
${ }^{1}$ School of Physical Education and Sport of Ribeirão Preto, University of São Paulo (USP), \\ Ribeirão Preto, São Paulo, Brazil, ${ }^{2}$ Postgraduate Program in Rehabilitation and Functional \\ Performance, Ribeirão Preto Medical School, University of São Paulo (USP), Ribeirão Preto, São \\ Paulo, Brazil. ${ }^{3}$ Laboratory of Molecular Biology of Exercise (LaBMEx), School of Applied \\ Sciences, University of Campinas (UNICAMP), Limeira, São Paulo, Brazil
}

Received January 26, 2020

Accepted June 2, 2020

Epub Ahead of Print November 2, 2020

\begin{abstract}
Summary
Autophagy plays an essential role in body homeostasis achievement. One of the main proteins involved in this process is the LC3I, which, after lipidation, leads to the formation of LC3II that participates in the formation and maturation of autophagosome. This descriptive study verified the responses of LC3II to LC3I proteins, as well as the time-course of this ratio in mice livers after different types of acute physical exercise protocols. Eight-week-old male C57BL/6 mice were maintained three per cage with controlled temperature $\left(22 \pm 2^{\circ} \mathrm{C}\right)$ on a 12:12-h light-dark normal cycle with food (Purina chow) and water ad libitum. Mice were randomly divided into four groups: control (CT, sedentary mice), resistance (RE, submitted to a single bout of resistance exercise), endurance (EE, submitted to a single bout of endurance exercise), and concurrent ( $C E$, submitted to a single bout of endurance combined with resistance exercise). The mice livers were extracted and used for the immunoblotting technique. The hepatic LC3B II/I ratio for the RE and EE groups were not altered during the different timepoints. For the CE group, there was a decrease in this ratio $12 \mathrm{~h}$ after exercise compared to time 0 and $18 \mathrm{~h}$. Also, the hepatic LC3B II/I ratios were not different among the acute physical exercise protocols along the time-course. The hepatic LC3B II/I ratio was not influenced by the endurance and resistance protocols but decreased in response to the concurrent protocol at $12 \mathrm{~h}$ after the stimulus.
\end{abstract}

\section{Key words}

Autophagy • Concurrent training • Endurance $\bullet$ Liver $\bullet$ Resistance

\section{Corresponding author}

Adelino S. R. da Silva. Address: Avenida Bandeirantes, 3900, Monte Alegre, 14040-907, Ribeirão Preto, São Paulo, Brazil. E-mail: adelinosanchez@usp.br

\section{Introduction}

Physical exercise is an activity performed systematically to improve cardiorespiratory and cardiovascular functions, structural adaptations, sports performance, as well as energy transfer and distribution (Guerreiro et al. 2016, Neufer et al. 2015). An acute bout of exercise can induce powerful stress defying cellular homeostasis. Therefore, exercise-induced positive adaptations require an optimal recovery period for stress adaptation and homeostasis unbalance reestablishment. One of the cellular processes involved in the maintenance of homeostasis is autophagy (Schwalm et al. 2015). Autophagy is defined as a process in which macromolecules or cell organelles are degraded for the repair and recycling of cytosolic materials, playing an important role in body homeostasis achievement (Cui et al. 2013, Mizushima 2007).

The main types of autophagy are macroautophagy, microautophagy, and chaperonemediated autophagy (Cecconi and Levine 2008, Klionsky 2005). While microautophagy and chaperone-mediated autophagy involve the direct participation of lysosomes, macroautophagy (hereafter referred to as autophagy) is responsible for the turnover of organelles or portions of

PHYSIOLOGICAL RESEARCH • ISSN 1802-9973 (online) 


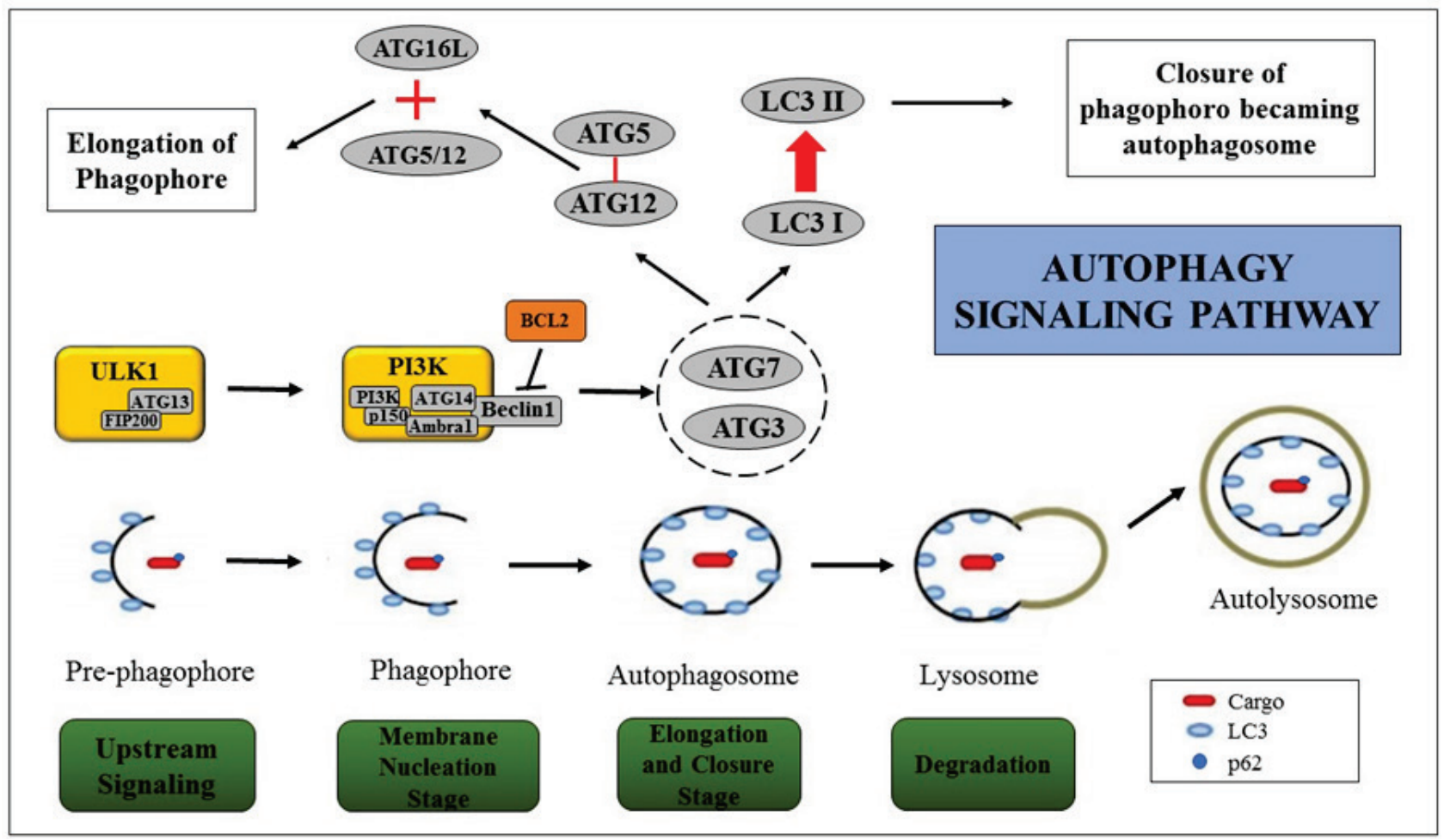

Fig. 1. Schematic model of the autophagy mechanism. The process begins with the formation of the ULK1 complex (ATG13 + FIP200), which leads to the initiation of the signaling pathway and activation of a second complex, PI3K (Beclin1 + P13K + ATG14 + p150 + Ambra 1). At this stage, BCL-2 is dissociated from Beclin1, and the PI3K complex is conducted to the phagophore membrane and initiates nucleation. ATG7 activation occurs, which will catalyze the conjugation of ATG5 and ATG12. The ATG5/ATG12 complex binds to ATG16L generating phagophore elongation. The ATG7 and ATG3 proteins generate the lipidation of LC3 I forming LC3 II, which conjugates to phosphatidylethanolamine and lead to the closure of phagophore, turning into an autophagosome. Finally, fusion with lysosomes occurs to form autolysosomes for degradation.

the cytosol surrounded by a double membrane vesicle, called autophagosome. At the end of the signaling pathway, this vesicle merges with the lysosome leading to degradation of its content (Cecconi and Levine 2008, Papackova and Cahova 2014). One of the main proteins involved in this process is the microtubule-associated protein 1 light chain 3 (LC3I), which after lipidation, leads to the formation of LC3II that participates in the formation and maturation of autophagosome (Vainshtein and Hood 2016). Figure 1 summarizes the autophagy process.

When the accumulation of dysfunctional organelles occurs, the proper functioning of autophagy is necessary for the degradation and release of the cell nutrients (Schneider and Cuervo 2014). The degradation generates free fatty acids, amino acids, and carbohydrates, which can be recycled to synthesize new cellular components or to produce adenosine triphosphate (Deter et al. 1967). These processes are particularly important for highly metabolically active organs such as the liver, which participates in the synthesis, metabolism, storage and redistribution of lipids, carbohydrates, and proteins. Under stress conditions, such as fasting and/or physical exercise, autophagy participates in the energy generation (He et al. 2012, Nonaka et al. 2017). Physical exercise can attenuate rates of lipogenesis and increase gene expressions linked to oxidative metabolism concomitant with whole-body fat oxidation enhancement (Townsend et al. 2019). The first evidence documented about autophagy and exercise was noted in 1980s. An increase in the number and size of autophagy vacuoles was observed in the liver and skeletal muscle of exercised animals (Salas et al. 1980). However, molecular functions of exercise-induced autophagy have recently been investigated.

Kristensen et al. (2018) verified that a 1-hour treadmill running was able to increase the liver LC3 II/I ratio immediately after exercise. After 2 hours of exercise, the LC3 II/I ratio returned to baseline values. To the best of our knowledge, the effects of different acute physical exercise protocols on the hepatic LC3 II/I ratio were not previously addressed. Therefore, this investigation aimed to verify the impact of resistance, endurance, and concurrent sessions on the LC3 II/I ratio in mice livers at different time-points. 


\section{Methods}

Animals

Eight-week-old male C57BL/6 mice were provided by the Central Animal Facility of the Ribeirão Preto campus of the University of São Paulo (USP). The mice were maintained in sterile micro-insulators, three animals per cage with controlled temperature $\left(22 \pm 2{ }^{\circ} \mathrm{C}\right)$ on a 12:12-h light-dark normal cycle with food (Purina chow) and water ad libitum. The experimental procedures were conducted according to the Brazilian College of Animal Experimentation (COBEA) and approved by the Committee on Ethics in the Use of Animals (CEUA) $\left(n^{\circ}: 2017.5 .30 .90 .8\right)$ of the School of Physical Education and Sport of Ribeirão Preto (EEFERP) from University of São Paulo. Mice were randomly divided into four groups: control (CT, sedentary mice), resistance (RE, submitted to a single bout of resistance exercise), endurance (EE, submitted to a single bout of endurance exercise), and concurrent (CE, submitted to a single bout of concurrent exercise).

\section{Experimental procedures}

Mice from the $\mathrm{RE}$ and $\mathrm{CE}$ groups were submitted to a 1-week adaptation period on a ladderclimbing (INSIGHT ${ }^{\mathrm{TM}}$, Ribeirão Preto, SP, Brazil) with and without external load (Kim HJ, 2015). The ladder had $1110 \mathrm{~mm}$ of height, $80^{\circ}$ of inclination, and 85 steps with a distance of $6 \mathrm{~mm}$ between each. Also, mice from the EE and CE groups were submitted to a 1-week adaptation period on a treadmill (INSIGHT ${ }^{\mathrm{TM}}$, Ribeirão Preto, SP, Brazil) for five days, $10 \mathrm{~min} /$ day, at a speed of $6 \mathrm{~m} \cdot \mathrm{min}^{-1}$.

\section{Incremental load test}

The incremental load test was performed 48 hours after the adaptation protocol, and started at an initial velocity of $6 \mathrm{~m} / \mathrm{min}$, at $0 \%$ of inclination with increments of $3 \mathrm{~m} / \mathrm{min}$ every $3 \mathrm{~min}$ until voluntary exhaustion. Maximum power (Pmax), defined as the animals' exhaustion velocity ( $\mathrm{m} / \mathrm{min})$, was used to prescribe the intensities for the $\mathrm{EE}$ and $\mathrm{CE}$ groups (Kuipers 1985).

\section{Acute physical exercise protocols}

For the RE group, mice first performed one climb without external load to warm-up. After that, mice performed ten climbs with a 2-minute recovery between each climb. An external load corresponding to $75 \%$ of body weight was applied at the base of the tail of each animal (Wang et al. 2015). Mice from the EE group ran at $60 \%$ of the Pmax without inclination for $60 \mathrm{~min}$ (Ferreira et al. 2007). Mice from the CE group performed one climb without external load to warm-up. After that, mice climbed five sets with $75 \%$ of body weight with a 2-minute recovery between each and ran at $60 \%$ of the Pmax at $0 \%$ of inclination for $30 \mathrm{~min}$. The animals were euthanized immediately, 6, 12, and $18 \mathrm{~h}$ after the acute physical exercise protocols. Figure 2 illustrates the schematic representation of the experimental procedures.

\section{Glucose levels}

The blood from the tail was collected before and immediately after the acute physical exercise protocols, and the glucose levels were measured by the Accu-Check Active glucometer (Accu-Chek ${ }^{\mathrm{TM}}$ Active model, Roche, Santo André, SP, Brazil).

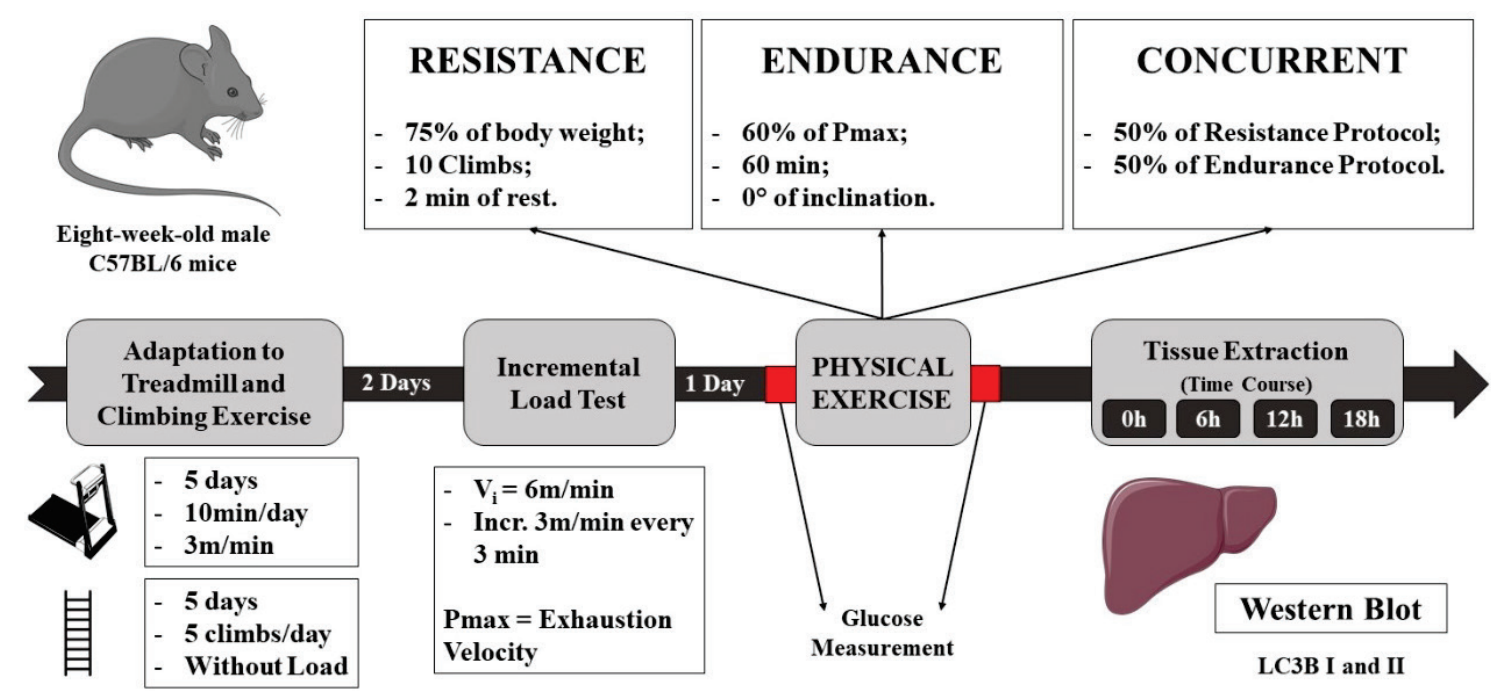

Fig. 2. Schematic representation of the experimental procedures. 


\section{Liver extraction}

Immediately, 6, 12, and $18 \mathrm{~h}$ after the acute physical exercise protocols, the mice were anesthetized by an intraperitoneal administration of xylazine (10 mg/kg body weight) and ketamine $(100 \mathrm{mg} / \mathrm{kg}$ body weight). As soon as the loss of pedal reflexes confirmed the effect of anesthesia, the livers were removed, washed with saline, and used for the immunoblotting technique.

\section{Immunoblotting technique}

The immunoblotting technique was performed as previously described (da Rocha et al. 2015, da Rocha et al. 2016, Morais et al. 2018, Pereira et al. 2015a, Pereira et al. 2015b). Specific antibodies [anti-LC3B (3868S), and anti-alpha tubulin (2144S)] from Cell Signalling Technology (Cell Signalling Technology, MA, USA) were used. Routine chemical reagents were obtained from Sigma Chemical Corporation (St. Louis, MO, USA). The primary antibodies were utilized at a dilution of 1:1.000, and the secondary antibody (7074S) from Cell Signaling Technology (Cell Signaling Technology, MA, USA) was utilized at a dilution between $1: 10.000$ and 1:20.000. Images were acquired by the C-Digit Blot Scanner (LI-COR, Lincoln, Nebraska, USA) and quantified using the software Image Studio for C-DiGit ${ }^{\mathrm{TM}}$ Blot Scanner.

\section{Statistics analysis}

Results are expressed as the mean \pm standard error of the mean (SE). The Shapiro-Wilk's W-test was used to verify data normality, and Levene's test was used to test the homogeneity of variances. One-way analysis of variance (ANOVA), followed by post-hoc Bonferroni's test when necessary, or Kruskal-Wallis test, followed by post-hoc Dunn's test when necessary, were used to verify the effects of acute physical exercise protocols at different time-points. All analyzes were bilateral, and the significance level was set at $\mathrm{p}<0.05$. Statistical analyses were performed using GraphPad Prism 8 software for Windows (IBM, Chicago, IL).

\section{Results}

\section{Body weight, training load, and exhaustion time}

Table 1 shows the body weight, external load for the RE and $\mathrm{CE}$ groups, as well as the maximum power for the EE and CE groups. Regarding body weight, there was no difference between the experimental groups.

\section{Basal and post-exercise glycemia}

Table 2 shows that the basal and post-exercise glycemia was not different between the experimental groups. The CE group presented a reduction of glycemia after exercise compared to its basal level.

Effects of the different acute physical exercise protocols on the hepatic LC3B II/I ratio

The LC3B II protein is essential for autophagosome formation. During the autophagy process, the lipidation of LC3B I to LC3B II occurs. When the

Table 1. Body weight, external load, and maximal power for the experimental groups.

\begin{tabular}{lcccc}
\hline Parameters & CT & RE & EE & CE \\
\hline Body weight $(g)$ & $23.46 \pm 1.23$ & $23.64 \pm 1.02$ & $22.93 \pm 1.14$ & $21.7 \pm 0.98$ \\
External load $(\mathrm{g})$ & - & $18.3 \pm 1.06$ & - & $16.9 \pm 0.81$ \\
Maximum power $(\mathrm{m} / \mathrm{min})$ & - & - & $20.6 \pm 3.47$ & $22.8 \pm 2.11$ \\
\hline
\end{tabular}

Data correspond to the mean \pm standard error of the mean (SE) of $n=5$ mice. CT: sedentary mice, RE: mice submitted to a single bout of resistance exercise, EE: mice submitted to a single bout of endurance exercise, CE: mice submitted to a single bout of concurrent exercise.

Table 2. Basal and post-exercise glycemia for the experimental groups.

\begin{tabular}{lcccc}
\hline Glycemia & CT & RE & EE & CE \\
\hline Basal $(\mathrm{mg} / \mathrm{dl})$ & $157.4 \pm 5.51$ & $173.6 \pm 7.94$ & $164.4 \pm 5.59$ & $154.6 \pm 6.05$ \\
Post-exercise $(\mathrm{mg} / \mathrm{dl})$ & - & $187.2 \pm 12.25$ & $147.8 \pm 24.14$ & $126.0 \pm 10.4^{*}$ \\
\hline
\end{tabular}

Data correspond to the mean \pm standard error of the mean (SE) of $n=5$ mice. CT: sedentary mice, RE: mice submitted to a single bout of resistance exercise, EE: mice submitted to a single bout of endurance exercise, CE: mice submitted to a single bout of concurrent exercise. ${ }^{*} \mathrm{p}<0.05$ versus basal glycemia for the same group. 
A
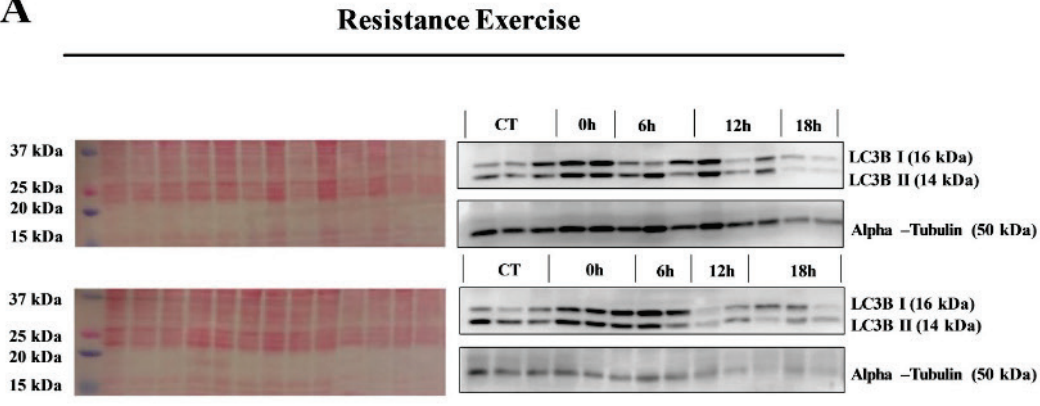

C Endurance Exercise
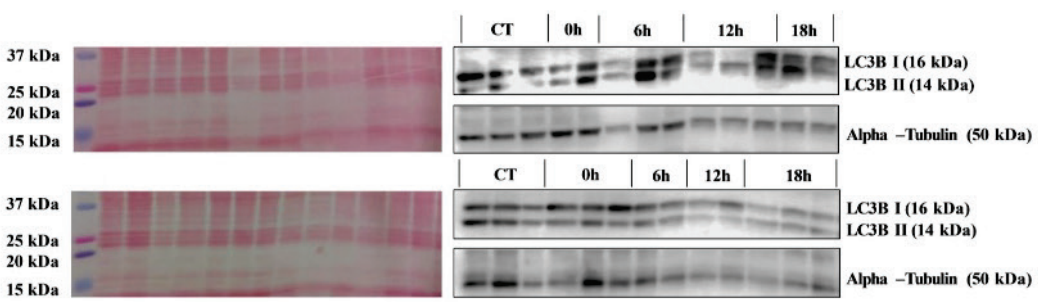

$\mathbf{F}$
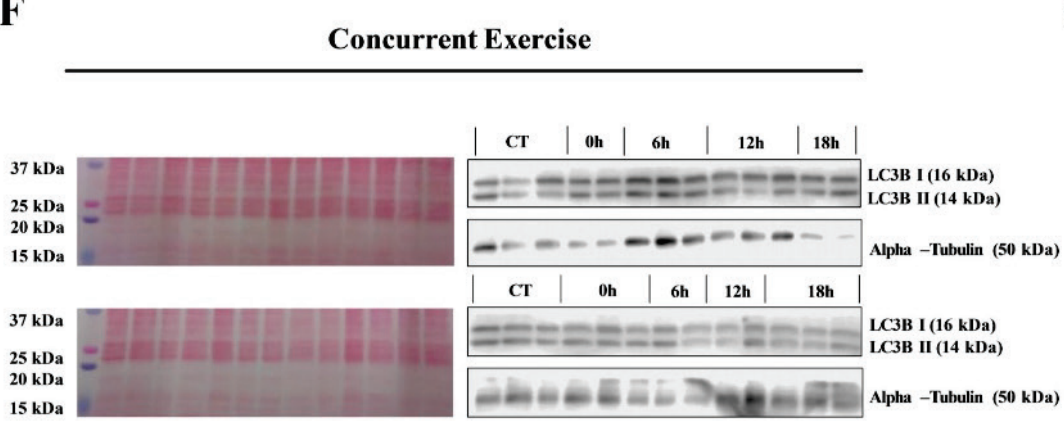

B

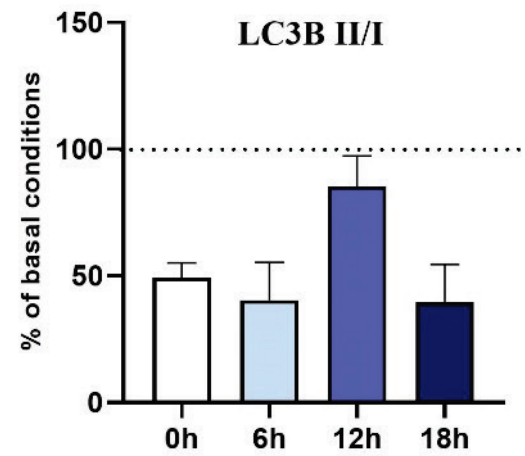

D

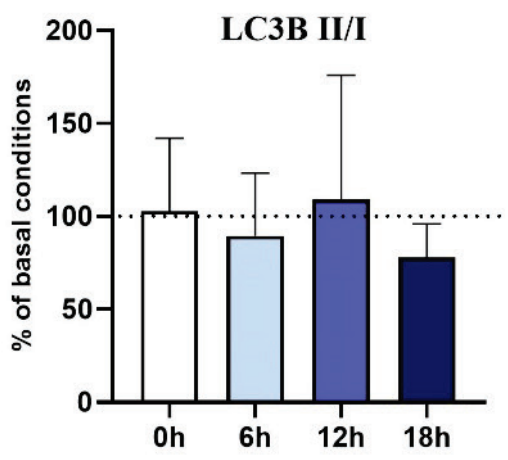

G

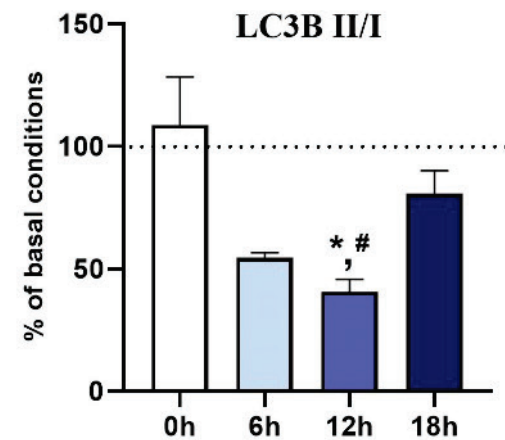

$\mathbf{H}$
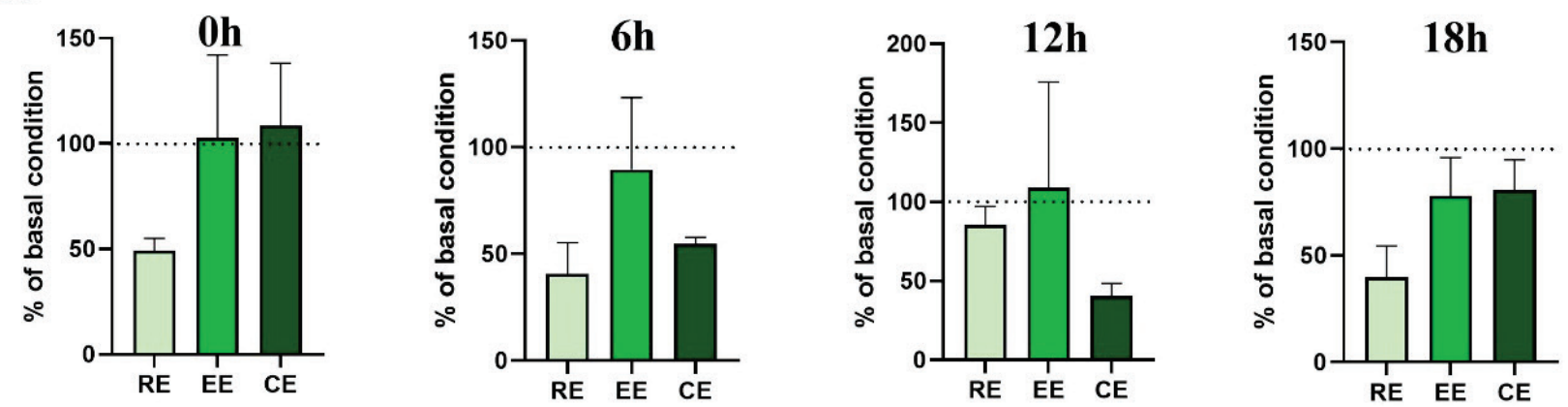

Fig. 3. A, C, E) Representative Ponceau and original bands with $k D a$ for each protein. B) Percentage to the basal condition of the LC3B II to LC3B I ratio in the liver after the resistance exercise, D) endurance exercise, and F) concurrent exercise at $0,6,12$, and 18 hours post-exercise. $\mathbf{H}$ ) Comparison of the different types of acute physical exercise protocols on the LC3B II/I ratio at $0,6,12$, and 18 hours post-exercise. ${ }^{*} p<0.05$ versus $0 \mathrm{~h}, \# p<0.05$ versus $18 \mathrm{~h}$. Data correspond to the mean $\pm S E$ of $n=5 /$ mice. 
LC3B II/I ratio is up or down-regulated, we can suggest that autophagy is present or absent, respectively. Figures $3 \mathrm{~A}, 3 \mathrm{C}$, and $3 \mathrm{~F}$ demonstrate the representative Ponceau and original bands with $\mathrm{kDa}$ of the hepatic LC3B II/I ratios immediately, 6,12 , and $18 \mathrm{~h}$ after the acute physical exercise protocols. Figure $3 \mathrm{~B}$ and $3 \mathrm{D}$ show that the hepatic LC3B II/I ratio for the RE and EE groups were not altered during the time-course. Figure $3 \mathrm{G}$ shows that the hepatic LC3B II/I ratio for the CE group decreased significantly $12 \mathrm{~h}$ after exercise compared to 0 and $18 \mathrm{~h}$. Figure $\mathrm{H}$ displays the hepatic LC3B II/I ratios were not different among the acute physical exercise protocols at any time-point.

\section{Discussion}

The main finding of this study was that hepatic LC3B II/I ratio evaluated $12 \mathrm{~h}$ after the CE protocol was attenuated compared to the 0 and $12 \mathrm{~h}$, while there was no difference for this ratio among the EE and RE groups along the time-course. This is the first investigation showing the effects of $\mathrm{RE}$ and $\mathrm{CE}$ on the hepatic protein contents of the LC3B II/I ratio. Regarding the glycemia, the EE group did not exhibit a difference between basal and post-exercise situations. In agreement with our study, other investigations visualized that a single bout of endurance exercise did not change glycemia, probably because the hepatic glucose production is higher during the exercise session, compensating the higher glucose uptake (Adams 2013). On the other hand, in response to resistance exercise, glycemia was attenuated in some studies (Black et al. 2010, Liu et al. 2019, Yardley et al. 2013), differently from our RE group that did not present statistical difference, probably because the exercise training was not intense enough. For the concurrent group, the glycemia was lower after exercise compared to basal levels, the same as demonstrated by Yardley et al. (2012). One possible explanation is that the first bout of exercise (i.e., RE) reduced blood glucose levels by stimulating glucose transport (Krisan et al. 2004). When the second bout of exercise (i.e., EE) started, the hepatic glucose production did not overcome the glucose uptake.

Kristensen et al. (2018) verified an increase in the hepatic LC3B II/I ratio immediately after 1 hour of treadmill running at $15 \mathrm{~m} / \mathrm{min}$ with $10^{\circ}$ of inclination, which was linked to enhanced autophagy. After 2 hours of exercise, the LC3B II/I ratio returned to the basal levels, indicating a transient increase in exercise-induced autophagy. In accordance, Kwon et al. (2019) verified that five days of moderate-intensity exercise increased LC3B II/I ratio in mice livers. On the other hand, our EE protocol did not lead to significant changes in the hepatic LC3B II/I ratios at $0,6,12$, and $18 \mathrm{~h}$ post-exercise. Comparing our endurance exercise protocol with those used by Kristensen et al. (2018) and Kwon et al. (2019), we can conclude that the treadmill inclination and total exercise volume contributed to the lack of significant results in our investigation.

He et al. (2012) visualized an increase in autophagosome numbers in skeletal and cardiac muscles after 30 minutes of running, reaching a plateau at 80 minutes. This increase was caused by lipidation of LC3I and degradation of p62 protein. Also, the authors concluded that autophagy after acute endurance exercise was present in other organs involved in energy homeostasis such as the pancreas, adipose tissue, and liver. In the same study, the treadmill was also inclined at $10^{\circ}$, being a possible explanation for the increase in autophagosome and autophagy induction. Fry et al. (2012) demonstrated that an acute resistance exercise decreased the LC3B II/I ratio in the skeletal muscle of adolescent and elderly subjects due to a reduction in the LC3II since LC3I was unchanged. Once the conversion of LC3I to LC3II is a marker of increased autophagy, the authors concluded that this protocol led to an autophagic flux reduction (Fry et al. 2012). On the other hand, Pinto et al. (2020) did not find significant changes in the LC3B II/I $2 \mathrm{~h}$ after an acute resistance exercise protocol, as well as Glynn et al. (2010) did not observe a modulation of the LC3II protein content after 1 hour of resistance exercise. Regarding the hepatic tissue, the combination of fasting, acute resistance exercise, and protein ingestion also did not change the LC3B II/I ratio (Pinto et al. 2020).

To the best of our knowledge, this is the first study to investigate the hepatic LC3B II/I ratio after an acute bout of concurrent exercise. Interestingly, we found a significant decrease of this autophagic marker $12 \mathrm{~h}$ after the exercise stimulus compared to 0 and $18 \mathrm{~h}$. This decrement may be explained by the reduction of LC3II protein levels at $12 \mathrm{~h}$ compared with the other timepoints. Smiles et al. (2016) demonstrated a decrease in LC3II protein levels 2 and $8 \mathrm{~h}$ after a concurrent exercise in skeletal muscle of individuals who ingested alcohol and carbohydrate. Also, the authors did not observe a significant change in the AMP-activated protein kinase protein, suggesting that autophagy could be repressed. Further investigations regarding the effects of concurrent training on hepatic autophagy are necessary for a better 
comprehension of this relationship.

Although not significant, the hepatic LC3B II/I ratios of the RE group were lower in comparison with the $\mathrm{EE}$ and CE groups at 0 and $18 \mathrm{~h}$. These data may be linked to the lower volume of the RE ( $\approx 20 \mathrm{~min})$ compared to the $\mathrm{EE}(\approx 150 \mathrm{~min})$ and $\mathrm{CE}(\approx 40 \mathrm{~min})$ sessions. A limitation of the present study was the difference in our exercise protocols compared to those described by other authors (He et al. 2012, Kristensen et al. 2018, Kwon et al. 2019), which indicated that treadmill inclination or total exercise volume contributed to their significant alterations in the hepatic LC3B II/I ratios. For future investigations, it would be interesting to insert two groups performing the same volume of endurance exercise but with different inclinations (i.e., $0^{\circ}$ versus $10^{\circ}$ treadmill inclination).

In conclusion, one acute session of resistance or endurance was not able to generate significant changes in the hepatic LC3B II/I ratios at different time-points. On the other hand, the hepatic LC3B II/I decreased 12h after the concurrent protocol compared to 0 and $18 \mathrm{~h}$. Although the hepatic LC3B II/I ratios were not different among the acute physical exercise protocols at any time-point, further studies should verify the chronic effects of these exercise protocols and their relationships with hepatic functional and morphological adaptations.

\section{Conflict of Interest}

There is no conflict of interest.

\section{Acknowledgements}

The present work received financial support from the São Paulo Research Foundation (FAPESP, process numbers 2017/09038-1 and 2019/10875-0), National Council for Scientific and Technological Development (CNPq, process number 301279/2019-5), and the Coordination for the Improvement of Higher Education Personnel (CAPES, finance code 001).

\section{Author's contributions}

The substantial contributions to conception and design, or acquisition of data, or analysis and interpretation of data: Marafon B.B, Pinto A.P, da Rocha A.L, Rovina R.L and da Silva A.S.R. Involvement in drafting the manuscript or revising it critically for important intellectual content: Marafon B.B, Pinto A.P, da Rocha A.L, Rovina R.L, Pauli J.R, de Moura L.P, Cintra D.E, Ropelle E.R, and da Silva A.S.R. Final approval of the version to be published: Marafon B.B, Pinto A.P, da Rocha A.L, Rovina R.L, Pauli J.R, de Moura L.P, Cintra D.E, Ropelle E.R, and da Silva A.S.R.

\section{References}

ADAMS OP: The impact of brief high-intensity exercise on blood glucose levels. Diabetes Metab Syndr Obes 6: 113-122, 2013. https://doi.org/10.2147/DMSO.S29222

BLACK LE, SWAN PD, ALVAR BA: Effects of intensity and volume on insulin sensitivity during acute bouts of resistance training. J Strength Cond R 24: 1109-1116, 2010. https://doi.org/10.1519/JSC.0b013e3181cbab6d

CECCONI F, LEVINE B: The role of autophagy in mammalian development: cell makeover rather than cell death. Dev Cell, 15, 344-357, 2008. https://doi.org/10.1016/j.devcel.2008.08.012

CUI J, GONG Z, SHEN H-M: The role of autophagy in liver cancer: molecular mechanisms and potential therapeutic targets. Biochim Biophys Acta 1836: 15-26, 2013. https://doi.org/10.1016/j.bbcan.2013.02.003

DA ROCHA AL, PEREIRA BC, PAULI JR, CINTRA DE, DE SOUZA CT, ROPELLE ER, DA SILVA AS: Downhill running-based overtraining protocol improves hepatic insulin signaling pathway without concomitant decrease of inflammatory proteins. PLoS One 10: e0140020, 2015. https://doi.org/10.1371/journal.pone.0140020

DA ROCHA AL, PEREIRA BC, PAULI JR, DE DOUZA CT, TEIXEIRA GR, LIRA FS, CINTRA DE, ROPELLE ER, JUNIOR CR, DA SILVA AS: Downhill running excessive training inhibits hypertrophy in mice skeletal muscles with different fiber type composition. J Cell Physiol 231: 1045-1056, 2016. https://doi.org/10.1002/jep.25197

DETER RL, BAUDHUIN P, DE DUVE C: Participation of lysosomes in cellular autophagy induced in rat liver by glucagon. J Cell Biol 35: C11, 1967. https://doi.org/10.1083/jcb.35.2.C11

FERREIRA JC, ROLIM NP, BARTHOLOMEU JB, GOBATTO CA, KOKUBUN E, BRUM PC: Maximal lactate steady state in running mice: effect of exercise training. Clin Exp Pharmacol Physiol 34: 760-765, 2007. https://doi.org/10.1111/j.1440-1681.2007.04635.x 
FRY CS, DRUMMOND MJ, GLUNN EL, DICKINSON JM, GUNDERMANN DM, TIMMERMAN KL, WALKER DK, VOLPI E, RASMUSSEN BB: Skeletal muscle autophagy and protein breakdown following resistance exercise are similar in younger and older adults. J Gerontol A Biol Sci Med Sci 68: 599-607, 2012. https://doi.org/10.1093/gerona/gls209

GLYNN EL, FRY CS, DRUMMOND MJ, DREYER HC, DHANANI S, VOLPI E, RASMUSSEN BB: Muscle protein breakdown has a minor role in the protein anabolic response to essential amino acid and carbohydrate intake following resistance exercise. Am J Physiol Regul Integr Comp Physiol 299: R533-R540, 2010. https://doi.org/10.1152/ajpregu.00077.2010

GUERREIRO L, ROCHA A, MARTINS C, RIBEIRO J, WALLY C, STRIEDER D, CARISSIMI CG, OLIVEIRA MG, PEREIRA AA, BIONDI HS, MONSERRAT JM, GONÇALVES CAN: Oxidative status of the myocardium in response to different intensities of physical training. Physiol Res 65: 737-749, 2016. https://doi.org/10.33549/physiolres.933185

HE C, BASSIK MC, MORESI V, SUN K, WEI Y, ZOU Z, AN Z, LOH J, FISHER J, SUN Q, KORSMEYER S, PACKER M, MAY HI, HILL JA, VIRGIN HW, GILPIN C, XIAO G, BASSEL-DUBY R, SCHERER PE, LEVINE B: Exercise-induced BCL2-regulated autophagy is required for muscle glucose homeostasis. Nature 481: 511-515, 2012. https://doi.org/10.1038/nature10758

KIM HJ, SO B, CHOI M, KANG D, SONG W: Resistance exercise training increases the expression of irisin concomitant with improvement of muscle function in aging mice and humans. Exp Gerontol 70: 11-17, 2015. https://doi.org/10.1016/j.exger.2015.07.006

KLIONSKY DJ: The molecular machinery of autophagy: unanswered questions. J Cell Sci 118: 7-18, 2005. https://doi.org/10.1242/jcs. 01620

KRISAN AD, COLLINS DE, CRAIN AM, KWONG CC, SINGH MK, BERNARD JR, YASPELKIS III BB: Resistance training enhances components of the insulin signaling cascade in normal and high-fat-fed rodent skeletal muscle. J Appl Physiol 96: 1691-1700, 2004. https://doi.org/10.1152/japplphysiol.01054.2003

KRISTENSEN CM, JESSEN H, RINGHOLM S, PILEGAARD H: Muscle PGC-1 $\alpha$ in exercise and fasting-induced regulation of hepatic UPR in mice. Acta Physiol (Oxf) 224: e13158, 2018. https://doi.org/10.1111/apha.13158

KUIPERS, H: VERSTAPPEN FTJ, KEIZER HA, GEURTEN P, VAN KRANENBURG G: Variability of aerobic performance in the laboratory and its physiologic correlates. Int J Sports Med 6: 197-201, 1985. https://doi.org/10.1055/s-2008-1025839

KWON I, SONG W, JANG Y, CHOI MD, VINCI DM, LEE Y: Elevation of hepatic autophagy and antioxidative capacity by endurance exercise is associated with suppression of apoptosis in mice. Ann Hepatol 19: 69-78, 2020. https://doi.org/10.1016/j.aohep.2019.08.010

LIU Y, YE W, CHEN Q, ZHANG Y, KUO C-H, KORIVI M: Resistance exercise intensity is correlated with attenuation of HbAlc and insulin in patients with type 2 diabetes: A systematic review and meta-analysis. Int J Environ Res Health 16: 140-160, 2019. https://doi.org/10.3390/ijerph16010140

MIZUSHIMA N: Autophagy: process and function. Genes Dev 21: 2861-2873, 2007. https://doi.org/10.1101/gad.1599207

MORAIS GP, DA ROCHA AL, PINTO AP, OLIVEIRA L, DE VICENTE LGFERREIRA GN, DE FREITAS EC, DA SILVA ASR: Uphill running excessive training increases gastrocnemius glycogen content in C57BL/6 mice. Physiol Res 67: 107-115, 2018. https://doi.org/10.33549/physiolres.933614

NEUFER PD, BAMMAN MM, MUOIO DM, BOUCHARD C, COOPER DM, GOODPASTER BH, BOOTH FW, KOHRT WM, GERSZTEN, MATTSON MP, HEPPLE RT, KRAUS WE, REID MB, BODINE SC, JAKICIC JM, FLEG JL, WILLIAMS JP, JOSEPH L, EVANS M, MARUVADA P, RODGERS M, ROARY M, BOYCE AT, DRUGAN JK, HOENING JI, INGRAHAM RH, KROTOSKI D, GARCIA-CAZARIN M, MCGOWAN JA, LAUGHLIN MR: Understanding the Cellular and Molecular Mechanisms of Physical Activity-Induced Health Benefits. Cell Metab 22: 4-11, 2015. https://doi.org/10.1016/j.cmet.2015.05.011

NONAKA Y, URASHIMA S, INAI M, NISHIMURA S, HIGASHIDA K, TERADA S: Effects of rapid or slow body weight reduction on intramuscular protein degradation pathways during equivalent weight loss on rats. Physiol Res 66: 823-831, 2017. https://doi.org/10.33549/physiolres.933502 
PAPACKOVA Z, CAHOVA M: Important role of autophagy in regulation of metabolic processes in health, disease and aging. Physiol Res 63: 409-420, 2014.

PEREIRA BC, DA ROCHA AL, PAULI JR, ROPELlE ER, DE SOUZA CT, CINTRA DE, SANT'ANA MR, DA SILVA ASR: Excessive eccentric exercise leads to transitory hypothalamic inflammation, which may contribute to the low body weight gain and food intake in overtrained mice. Neuroscience 311: 231-242, 2015a. https://doi.org/10.1016/j.neuroscience.2015.10.027

PEREIRA BC, LUCAS G, DA ROCHA AL, PAULI JR, ROPELLE ER, CINTRA DE, DE SOUZA CT, BUENO CR, DA SILVA ASR: Eccentric exercise leads to glial activation but not apoptosis in mice spinal cords. Int J Sports Med 36: 378-385, 2015b. https://doi.org/10.1055/s-0034-1395589

PINTO AP, VIEIRA TS, MARAFON BB, BATITUCCI G, CABRERA EMB, DA ROCHA AL, KOHAMA EB, RODRIGUES KC, DE MOURA LP, PAULI JR, CINTRA DE, ROPELlE ER, FREITAS EC, DA SILVA ASR: The combination of fasting, acute resistance exercise, and protein ingestion led to different responses of autophagy markers in gastrocnemius and liver samples. Nutrients 12: 641-656, 2020. https://doi.org/10.3390/nu12030641

SALAS M, TUCHWEBER B, KOUROUNAKIS P: Liver ultrastructure during acute stress. Pathol Res Pract 167: $217-$ 233, 1980. https://doi.org/10.1016/S0344-0338(80)80052-5

SCHNEIDER JL, CUERVO AM: Autophagy and human disease: emerging themes. Curr Opin Genet Dev 26: 16-23, 2014. https://doi.org/10.1016/j.gde.2014.04.003

SCHWALM C, JAMART C, BENOIT N, NASLAIN D, PRÉMONT C, PRÉVET J, THIENEN RV, DELDICQUE L, FRANCAUX M: Activation of autophagy in human skeletal muscle is dependent on exercise intensity and AMPK activation. FASEB J, 29: 3515-3526, 2015. https://doi.org/10.1096/fj.14-267187

SMILES WJ, PARR EB, COFFEY VG, LACHAM-KAPLAN O, HAWLEY JA, CAMERA DM: Protein coingestion with alcohol following strenuous exercise attenuates alcohol-induced intramyocellular apoptosis and inhibition of autophagy. Am J Physiol Endocrinol Metab 311: E836-E849, 2016. https://doi.org/10.1152/ajpendo.00303.2016

TOWNSEND LK, GANDHI S, SHAMSHOUM H, TROTTIER SK, MUTCH DM, REIMER RA, SHEARER J, LEBLANC PJ, WRIGHT DC: Exercise and Dairy Protein have Distinct Effects on Indices of Liver and Systemic Lipid Metabolism. Obesity (Silver Spring) 28: 97-105, 2020. https://doi.org/10.1002/oby.22621

VAINSHTEIN A, HOOD DA: The regulation of autophagy during exercise in skeletal muscle. J Appl Physiol 120: 664-673, 2016. https://doi.org/10.1152/japplphysiol.00550.2015

WANG W, CHOI RH, SOLARES GJ, TSENG H-M, DING Z, KIM K, IVY JL: L-Alanylglutamine inhibits signaling proteins that activate protein degradation, but does not affect proteins that activate protein synthesis after an acute resistance exercise. Amino acids 47: 1389-1398, 2015. https://doi.org/10.1007/s00726-015-1972-7

YARDLEY JE, KENNY GP, PERKINS BA, RIDDELL MC, BALAA N, MALCOLM J BOULAY P, KHANDWALA F, SIGAL RJ: Resistance versus aerobic exercise: acute effects on glycemia in type 1 diabetes. Diabetes Care 36: 537-542, 2013. https://doi.org/10.2337/dc12-0963

YARDLEY JE, KENNY GP, PERKINS BA, RIDDELL MC, MALCOLM J, BOULAY P, KHANDWALA F, SIGAL RJ: Effects of performing resistance exercise before versus after aerobic exercise on glycemia in type 1 diabetes. Diabetes Care 35: 669-675, 2012 https://doi.org/10.2337/dc11-1844 